
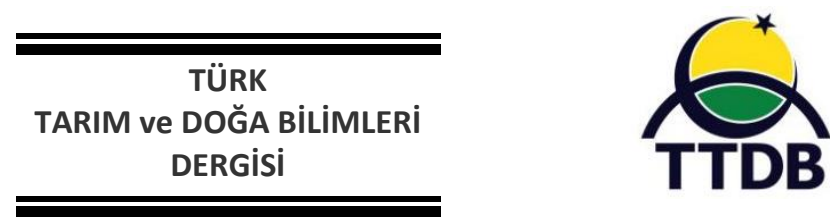

www.dergipark.gov.tr/turkjans

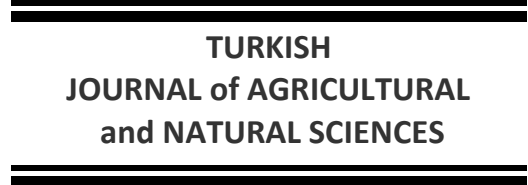

Araştırma Makalesi

\title{
Iğdır Koşullarında Mera Tesisinde Kullanılabilecek Bazı Buğdaygil-Baklagil Tür ve Karışımların Kalite Performansları \&
}

\author{
Seda AKBAY TOHUMCU* Süleyman TEMEL \\ Iğdır Üniversitesi Ziraat Fakültesi Tarla Bitkileri Bölümü, Iğdır \\ *: Sorumlu yazar: seda.akbay@igdir.edu.tr
}

Geliş Tarihi: 19.12.2019 Düzeltme Geliş Tarihi: 09.06.2020 Kabul Tarihi: 09.06.2020

\section{Öz}

Bu çalışma hayvancılığın büyük öneme sahip olduğu ve daha önceden mera karışımı ile ilgili herhangi bir çalışmanın yapılmadığı Iğdır ili taban alanlarda kurulabilecek yapay mera tesisi için uygun yem bitkisi tür ve karışımlarının ot kalitesi açııından performanslarını belirlemek amacıyla yürütülmüştür. Deneme 2014 yılında tesadüf blokları deneme desenine göre üç tekerrürlü olarak kurulmuş ve 3 yıl süre ile yürütülmüştür. Araştırmada yonca (Y), gazal boynuzu (GB), kamışsı yumak (KY) ve kııçıksız brom (KB)'un yalın ekim, ikili ve üçlü karışımları incelemeye alınmıştır. Çalışmada incelenen ham protein (HP), ADF (asit deterjanda çözünmeyen lif), NDF (nötral deterjanda çözünmeyen lif), sindirilebilir kuru madde (SKM), nispi yem değeri (NYD) ve ham protein verimi (HPV) yıllar ve karışım konuları arasında önemli farklııklar göstermiştir. Araştırma sonucunda yalın ekilen baklagiller buğdaygillerden, ikili karışımlar üçlü karışımlardan genellikle daha yüksek HP, SKM ve NYD'ne ve daha düşük ADF, NDF ve HPV'ne sahip olmuştur. Yine yoncanın buğdaygillerle oluşturduğu ikili karışımlar GB ile oluşturulan ikili karışımlara göre genellikle daha yüksek HP, HPV ve ADF içeriğine ve daha düşük NDF ve SKM'ye sahip olmuştur. Oysa NYD açısından ikili karışımlar (KB+GB hariç) aynı istatistiki grupta yer almışıı. Sonuç olarak; incelenen parametreler açısından bölge için en uygun ikili karışımların yonca bitkisinin yer aldığı karışımlar olduğu ortaya konulmuştur.

Anahtar Kelimeler: Besin içerikleri, İkili ve üçlü karışımlar, Suni mera tesisi

\section{Determination of Some Quality Performances Forage Grass-Legume Species and Mixtures for Pasture Establishment Under Conditions of Igdir}

\begin{abstract}
This study was carried out to determine the qualit performances of the suitable forage species and mixtures for the pasture establishment under lowland conditions of Igdir, where there are no studies related to the pasture system, where is of great importance for the animal husbandary, during three periods. Research was established as randomized block design with three replications in 2014. In study, pure sowing and binary and ternary mixtures of alfalfa (A), birdsfoot trefoil (BT), tall fescue (TF) and smooth brome (SB) were investigated. The study showed significant differences between years and mixtures of crude protein (CP), acid detergent fiber (ADF), neutral detergent fiber (NDF), digestible dry matter (DDM) and relative feed value (RFV). In the research result, the pure-sown forage legumes and binary mixtures had higher CP, DDM and RFV than forage grasses and ternary mixtures, but lower ADF, NDF and CPY. Also, the binary mixtures of alfalfa with forage grasses generally had higher CP, CPY and ADF content and lower NDF and DDM than binary mixtures made with BT. With regards to RFV, however, the binary mixtures (except $\mathrm{SB}+\mathrm{BT}$ ) were included the same statistical group. Consequently; the most suitable binary mixtures for the region were found to be mixtures containing alfalfa plant in terms of examined parameters.
\end{abstract}

Keywords: Nutrient content, Binary and ternary mixtures, Artificial pasture establishment 


\section{Giriş}

Ülkemizde hayvancılığının en büyük sorunlarından birisi kaliteli kaba yem açığıdır. $\mathrm{Bu}$ sebepten hayvanlarımız yeterli beslenememekte ve elde edilen hayvansal ürünlerin miktarı ve kalitesi düşük olmaktadır. Bilim insanları ve üreticilerimiz gereksinim duyulan mevcut yem açığının kapatılabilmesi amacıyla farklı arayışlar içerisine girmişler ve ihtiyaç duyulan kaliteli kaba yemin arttırılması için öncelikli olarak meraların ıslah edilmesi ve bölgeye uygun yem bitkisi türlerin yetiştirilmesi gerektiğini vurgulamışlardır (Yolcu ve Tan, 2008; Yavuz ve Karadağ, 2016). Iğdır ili çayırmera alanlarının fazla oluşu hayvancılık için büyük bir potansiyel olarak gözükmektedir. Fakat ekstrem iklim koşulları ile toprak yapısındaki bozukluk gibi sebepler ve çayırmeraların bilinçsiz kullanımı sonucunda bu alanlar verimliliklerini büyük ölçüde kaybetmiştir. Bu nedenle ilde yem bitkileri tarımının arttırılması gerekmektedir (Temel ve Şahin, 2010).

Doğal mera alanlarının ıslahının ekonomik olmaması ve uzun bir süreyi kapsaması nedeniyle uygulanabilirliği düşüktür. $\mathrm{Bu}$ sebepten eksik kaliteli kaba yem gereksiniminin karşılanmasında bölgenin iklim şartlarına uygun yem bitkisi tür ve çeşitleri ile yapay çayır ve mera tesislerinin oluşturulması daha mantıklı bir çözüm sunmaktadır. Ayrıca suni mera tesisi amacı ile kullanılan çok yıllık baklagil-buğdaygil yem bitkisi karışımları verim ve kalite açısından yalın ekimlerden daha üstün bir yem materyali üretebilmektedir (Koç ve ark., 2004; Seydoşoglu ve Bengisu, 2019). Çünkü suni meraların botanik kompozisyonlarını oluşturan baklagil-buğdaygil yem bitkileri birbirlerini tamamlayıcı özellik göstermektedir. Buğdaygiller karbonhidrat yönünden, baklagiller ise protein bakımından zengin olup, daha dengeli bir beslenme materyali meydana getirmektedirler (Çınar ve ark., 2012).

Doğu Anadolu Bölgesinde yer alan Iğdır İlinde halkın büyük bir kısmı geçimini bitkisel ve özellikle de hayvansal üretim yaparak sağlamaktadır. Ancak Türkiye'deki diğer bölgelerimizde olduğu gibi Iğdır ilinde de mevcut hayvanlar yeteri kadar beslenememekte ve sonuçta arzulanan hayvansal üretim artışları sağlanamamaktadır. $\mathrm{Bu}$ artışı sağlayabilmenin tek yolu kaliteli kaba yem üretimini artırmaktır. Bu da tarla ziraatı içerisinde yem bitkileri yetiştiriciliğini artırmak ya da yapay çayır-mera tesisleri ile mümkün olacaktır. Ancak oluşturulacak olan suni çayırmera tesislerinden yüksek kaliteli ot elde edebilmek için öncelikli olarak bölgeye uygun tür ve karışımların saptanması gerekir. Bu amaç ile ülkemizde farklı araştırmacılar bulundukları bölgeye uygun karışımların belirlenmesi amacıyla pek çok çalışma yürütmüş ve önemli sonuçlar almışlardır (Albayrak, 2003; Özaslan Parlak ve Ekiz, 2006; Şahinoğlu ve Uzun, 2016; Yavuz ve Karadağ, 2016; Temel ve Akbay Tohumcu, 2019). Kurak iklim özelliğine sahip Iğdır coğrafyasında karışımların besin kompozisyonunu ortaya koyan yürütülmüş herhangi bir bilimsel çalışma bulunmamaktadır (Anonim, 2020).

$\mathrm{Bu}$ çalışma ile farklı serin mevsim buğdaygiller ile baklagil türlerinin yer aldığı saf, ikili ve üçlü karışım kombinasyonları oluşturularak kalite açısından performansları ortaya konulmaya çalışılmıştır.

\section{Materyal ve Yöntem}

Araştırma, 2014-2016 yıllarında, Iğdır ili Melekli Beldesi sınırları içerisinde yer alan Iğdır Üniversitesi Tarımsal Uygulama ve Araştırma Merkezi (IÜTUAM)'ne ait deneme sahasında (390 48'06.69" K, 440 34'58.30' yürütülmüştür. Araştırma alanı olarak seçilen bölge taban arazi özelliğinde ve $876 \mathrm{~m}$ rakıma sahiptir. Iğdır ilinin yıllık yağış miktarının düşük ve buharlaşmanın fazla olması sebebiyle Iğdır ili ülkemizin en kurak iklim bölgesi içerisinde yer almaktadır (Temel ve Şimşek, 2011).

Araştırma sahasının uzun yıllar (UY) ve çalışmanın yürütüldüğü yıllara ait sıcaklık, yağış miktarı ve nispi nem değerleri Çizelge 1'de sunulmuştur (Anonim, 2016). Buna göre 2014, 2015 ve 2016 yıllarına ait ortalama sıcaklık değerleri (sırasıyla $13.9{ }^{\circ} \mathrm{C}, 14.8^{\circ} \mathrm{C}, 12.8^{\circ} \mathrm{C}$ ), UY ortalama sıcaklık değerinin $\left(12.6{ }^{\circ} \mathrm{C}\right)$ üzerindedir. Düşen toplam yağış miktarı 2015 yılında $(302.4 \mathrm{~mm})$ uzun yıllar ortalamasından (UYO) (264.8 mm) daha fazla iken, 2014 (237.6 $\mathrm{mm}$ ) ve 2016 (207.5 mm) yıllarında, UYO'nın (264.8 mm) altında kalmıştır. Nispi nem değerinin ise; araştırmanın yürütüldüğü yıllarda (2014; \% 54.6, 2015; \%53.2 ve 2016; \%57.3) UYO'nın (\%51.6) üzerinde olduğu görülmüştür. $\mathrm{Bu}$ verilere göre araştırmanın yürütüldüğü yıllar, UYO göre daha kurak geçmiştir. 
Çizelge 1. Araştırmanın yürütüldüğü Iğdır illinin 2014, 2015, 2016 ve uzun yıllar ortalaması (UYO)’na (1990-2013) ait iklim değerleri**

\begin{tabular}{|c|c|c|c|c|c|c|c|c|c|c|c|c|}
\hline \multirow{3}{*}{ Aylar } & \multicolumn{4}{|c|}{ Sıcaklık ( $\left.{ }^{\circ} \mathrm{C}\right)$} & \multicolumn{4}{|c|}{ Yağış Miktarı (mm) } & \multicolumn{4}{|c|}{ Nispi Nem (\%) } \\
\hline & \multicolumn{4}{|c|}{ Temperature $\left({ }^{\circ} \mathrm{C}\right)$} & \multicolumn{3}{|c|}{ Rainfall (mm) } & \multicolumn{5}{|c|}{ Relative Humidity (\%) } \\
\hline & 2014 & 2015 & 2016 & UYO* & 2014 & 2015 & 2016 & UYO & 2014 & 2015 & 2016 & UYO \\
\hline Ocak & -4.5 & 1.2 & -1.3 & -3.1 & 15.3 & 2.2 & 24.7 & 13.5 & 78.0 & 63.3 & 68.2 & 64.0 \\
\hline Şubat & 2.1 & 4.3 & 4.6 & 0.3 & 3.6 & 4.4 & 6.2 & 15.4 & 55.2 & 59.5 & 63.7 & 57.1 \\
\hline Mart & 10.1 & 8.5 & 9.2 & 7.2 & 17.2 & 52 & 10 & 20.6 & 46.8 & 50.8 & 48.7 & 46.1 \\
\hline Nisan & 15.7 & 13.8 & 14.5 & 13.5 & 30.5 & 44.1 & 20.1 & 44.8 & 46.6 & 47.7 & 48.4 & 47.1 \\
\hline Mayıs & 19.6 & 18.3 & 18.5 & 17.9 & 49.9 & 41.5 & 23.5 & 50.7 & 52.3 & 52.9 & 55.3 & 48.4 \\
\hline Haziran & 23.5 & 25.1 & 22.6 & 22.9 & 34.6 & 27.8 & 25.7 & 31.7 & 42.3 & 40 & 51.1 & 42.3 \\
\hline Temmuz & 27.7 & 28.7 & 26 & 26.4 & 7.7 & 0.3 & 22 & 15.4 & 38.2 & 33.6 & 47.9 & 40.0 \\
\hline Ağustos & 28.1 & 27.2 & 27.2 & 26.4 & 5.0 & 14.3 & 4.1 & 9.6 & 36 & 40.7 & 45.3 & 40.7 \\
\hline Eylül & 22.4 & 22.6 & 20.4 & 20.6 & 15.2 & 1.4 & 5.9 & 12.7 & 42.6 & 43.6 & 49.9 & 46.7 \\
\hline Ekim & 13.6 & 16.6 & 12.5 & 13.7 & 27.1 & 96.2 & 12.9 & 21.8 & 66.1 & 71.3 & 69 & 58.9 \\
\hline Kasım & 5.4 & 9.2 & 3.7 & 5.7 & 20.5 & 4.5 & 17.3 & 16.6 & 72.8 & 66 & 70.5 & 61.5 \\
\hline Aralık & 3.3 & 1.5 & -3.8 & -0.7 & 11.0 & 13.7 & 35.1 & 11.9 & 77.8 & 68.8 & 69.8 & 66.5 \\
\hline Ort./Top. & 13.9 & 14.8 & 12.8 & 12.6 & 237.6 & 302.4 & 207.5 & 264.8 & 54.6 & 53.2 & 57.3 & 51.6 \\
\hline
\end{tabular}

**Anonim, 2016; *Uzun yıllar ortalaması

Araştırmanın yürütüldüğü Iğdır ili topraklarının bir kısmında bilinçsiz tarım uygulamaları ve ilin topoğrafik yapısı ve iklim özelliğinden dolayı tuzluluk problemi yaşanmaktadır. Dolayısı ile bu alanlar zaman içerisinde verimliliğini kaybetmiştir (Temel ve Şimşek, 2011). IÜTUAM topraklarında da verimliliğini kaybetmiş alanlar mevcuttur. Fakat deneme alanının belirlenmesinde aşırı tuzlu toprakların seçilmemesine özen gösterilmiştir. Ekimden önce deneme alanını temsil edecek şekilde $30 \mathrm{~cm}$ derinliğindeki farklı alanlardan toprak örnekleri alınmış ve analizler bu örneklerle gerçekleştirilmiştir. Analiz sonuçlarına göre deneme alanı topraklarının; tekstür sınıfının killi-tın, hafif tuzlu $(3 \mathrm{mmhos}$ $\mathrm{cm}^{-1}$ ) hafif alkalin özellikte $(\mathrm{pH}: 8.0)$, düşük organik madde içeriğine sahip (\%1.6), orta kireçli (\%6.53), elverişli fosfor içeriği yeterli (8.0 $\mathrm{kg} \mathrm{P}_{2} \mathrm{O}_{5}$ ) ve potasyum içeriğinin zengin olduğu (343 kg K2O) görülmüştür (Kacar, 1986).

Deneme 2014 yılında tesadüf blokları deneme desenine göre üç tekerrürlü olarak kurulmuş ve üç yıl süre ile yürütülmüştür. İlk yıl tesis yılı olarak değerlendirilmiş olup, herhangi bir veri alınmamıştır. Denemedeki her bir parsel $5 \mathrm{~m}$ uzunluğunda 6 sıradan oluşmuş olup, sıra aralıkları $25 \mathrm{~cm}$ olarak belirlenmiştir.

Araştırmada yonca (Medicago sativa L.), gazal boynuzu (Lotus corniculatus L.), kamışsı yumak (Festuca arundinacea Schreb.) ve kılçıksız brom (Bromus inermis Leyss.) bitki materyali olarak kullanılmıştır. Çalışmada kullanılan türler yalın, 2'li ve 3’lü karışım halinde ekilmiş, tür ve karışımların ekim oranları Çizelge 2'de sunulmuştur. Buna göre çalışma kapsamında 4'ü yalın, 4'ü ikili (\%30 baklagil, \%70 buğdaygil) ve 2'si üçlü (\%30 baklagil ve \%35'er buğdaygiller) karışım olmak üzere toplam 10 konu incelenmiştir.

Ekimler Nisan ayının ilk haftasında toprağın tavda olduğu dönemde yapılmıştır. Yalın ekim ve karışımların tohumluk miktarları; çimlendirme testi yapılarak ve tohumluk safiyetleri göz önünde bulundurularak yoncanın $2.0 \mathrm{~kg} / \mathrm{da}$, gazal boynuzunun $1 \mathrm{~kg} / \mathrm{da}$, kamışsı yumağın 2.0 kg/da (Açıkgöz, 2001) saf tohum miktarı esas alınarak hesaplanmıştır. Karışımlar \% 70 buğdaygil + \% 30 baklagil tohum oranları dikkate alınarak oluşturulmuştur. Dekara atılacak olan tohumluk miktarı, türlerin yalın ekimdeki tohum miktarlarının karışımda yer alan oranlarla çarpılması sonucunda belirlenmiştir. Üçlü karışımlarda ise iki buğdaygilin karışımdaki oranı eşit olacak şekilde (\%35+\%35) ayarlanmıştır. Daha sonra dekara belirlenen tohumluk miktarlarından yola çıkılarak, deneme parsellerine $\left(7.5 \mathrm{~m}^{2}\right)$ düşecek olan tohumluklar hesaplanmıştır. Sonra da her sıra için (toplam 6 sıra) ayrı ayrı tartılan tohumların ekimi markörle açılan çizilere yapılmıştır. Araştırmada gübre olarak amonyum sülfat (\%21 N), fosfor kaynağı olarak da triple süperfosfat (\%39-42 $\mathrm{P}_{2} \mathrm{O}_{5}$ ) kullanılmıştır. Yapılan toprak analizlerine göre; ilk yıl saf baklagillere 4 $\mathrm{kg} \mathrm{da}{ }^{-1} \mathrm{~N}$ ve $8 \mathrm{~kg} \mathrm{da}^{-1} \mathrm{P}_{2} \mathrm{O}_{5}$, yalın ekilen buğdaygillere ise $15 \mathrm{~kg} \mathrm{da}^{-1} \mathrm{~N}$ ve $5 \mathrm{~kg} \mathrm{da}^{-1} \mathrm{P}_{2} \mathrm{O}_{5}$ sağlayacak şekilde gübreleme yapılmıştır. Bakım 
yıllarında saf ekilen baklagillere azotlu gübre verilmemiş, sonbahar döneminde $8 \mathrm{~kg}$ fosfor verilmiştir. Araştırmanın 2. ve 3. yıllarında yalın olarak yetiştirilen buğdaygillere $10 \mathrm{~kg} \mathrm{da}^{-1} \mathrm{~N}$ uygulaması yapılmıştır (Tan, 2018). Baklagil buğdaygil karışımlarına ise her yıl $8 \mathrm{~kg} \mathrm{da}^{-1} \mathrm{P}_{2} \mathrm{O}_{5}$ (sonbahar döneminde), $5 \mathrm{~kg} \mathrm{da}^{-1} \mathrm{~N}$ (yarısı ilkbaharda kalan kısmı ise ilk biçimden sonra) verilmiştir (Açıkgöz, 2001). Deneme alanında yer alan bitkiler ihtiyaç duyulan dönemde yağmurlama sulama sistemi kullanılarak sulanmıştır. Deneme alanında yabancı ot kontrolü sıra üzerinde elle çapalama, parsel ve blok aralarında ise çapa makinesi ile yapılmıştır. Ayrıca denemenin ilk yılında yabancı ot baskısından dolayı parseller sık sık biçilmiştir.

Çizelge 2. Yalın ekim ve karışımların ekim oranları

\begin{tabular}{ll}
\hline Yalın ekim ve karışımlar & Ekim oranları \\
\hline Yonca & $\% 100$ \\
\hline Gazal Boynuzu & $\% 100$ \\
\hline Kamışsı Yumak & $\% 100$ \\
\hline Kılçıksız Brom & $\% 100$ \\
\hline Kamışsı Yumak + Yonca & $\% 70+\% 30$ \\
\hline Kamışsı Yumak + Gazal Boynuzu & $\% 70+\% 30$ \\
\hline Kılçıksız Brom + Yonca & $\% 70+\% 30$ \\
\hline Kılçıksız Brom + Gazal Boynuzu & $\% 70+\% 30$ \\
\hline Kamışsı Yumak + Kılçıksız Brom +Yonca & $\% 35+\% 35+\% 30$ \\
\hline Kamışsı Yumak + Kılçıksız Brom + Gazal Boynuzu & $\% 35+\% 35+\% 30$ \\
\hline
\end{tabular}

Hasat işlemleri; yalın ekimlerde çiçeklenme başlangıcında, karışımlarda ise baklagillerin biçim zamanı olan \% 10 çiçeklenme dönemi esas alınarak yapılmıştır. Araştırmanın ilk yılında yabancı ot yoğunluğundan dolayı örnek alımları yapılamamış, ikinci ve üçüncü yıllarda ise 3 kez biçim yapılmıştır. Hasat edilen bitkiler, oda şartlarında kurutulmuş sonrasında $60{ }^{0} C^{\prime}$ ye ayarlanmış etüvde sabit ağırlığa ulaşana kadar kurutulmuştur. Daha sonra kurutulan örnekler ot değirmeninde öğütülerek (1 $\mathrm{mm}$ çapında olacak şekilde), kimyasal analizler için hazır hale getirilmiştir. Buradaki amaç, yıllara göre yemlerin besin içeriklerini belirlemek olduğundan yıl içerisinde yapılan biçimlerden elde edilen verimler, ağırlık ortalamasına göre oranlanarak analiz için örnek miktarları belirlenmiştir.

Araştırmadaki yalın ekilen tür ve karışımların azot $(\mathrm{N})$ içeriği Kjeldahl yöntemi ile belirlenmiştir. Bulunan $\mathrm{N}$ değerleri 6.25 katsayısıyla çarpılmak suretiyle ham protein oranları (HPO) saptanmıştır (Kacar, 1972). Araştırmada incelenen tür ve karışımların HPO hesaplandıktan sonra kuru ot verimleriyle çarpılmış, ham protein verimi (HPV) belirlenmiştir. Nötr çözücülerde çözünmeyen lif (NDF) ve asit çözücülerde çözünmeyen lif (ADF) oranları Van Soest ve ark. (1991) tarafından belirtilen yöntem kullanılarak belirlenmiştir. ADF oranı ile sindirilebilir kuru madde oranı (SKM) hesaplanmıştır. Kuru madde sindirilebilirlik değerleri sindirilebilir enerji miktarını tahmin etmek için belirlenmektedir. Bu amaçla; Oddy ve ark. (1983) tarafından formülize edilen eşitlikle bitkilerin \%SKM oranları bulunmuştur (Sindirilebilir Kuru Madde $(\mathrm{SKM})=88.9-(0.779 \times$ \%ADF) $) . \quad$ Nispi yem değerleri ise, ADF ve NDF sonuçları kullanılarak hesaplanmıştır (Sheaffer ve ark.,1995).

Veriler, iki yıl tekrarlanan tesadüf blokları deneme desenine göre SPSS istatistik paket programında varyans analizine tabi tutulmuş ve önemli çıkan ortalamaların karşılaştııılması Duncan testine göre gruplandırılmıştır.

\section{Bulgular ve Tartışma Ham Protein Oranı}

Iğdır ekolojik koşullarında yapay mera tesisinde yer alabilecek çok yıllık serin iklim buğdaygil-baklagil karışımlarının denendiği bu çalışmada, saf ve karışım ekimlerde elde edilen ham protein sonuçları Çizelge 3'te verilmiştir. Yapılan istatistik analiz sonucu HPO bakımından yıllar arasında önemli bir farklılık bulunmazken, konular ve yıl $x$ konu interaksiyonu arasında önemli farklılıklar belirlenmiştir. Konular içerisinde en yüksek HPO gazal boynuzu (\%15.84) ve yonca türünde (\%15.22) belirlenmiş ve istatistiki olarak aynı grupta yer almışlardır. En düşük HPO ise yalın ekilen kamışsı yumak bitkisinde ölçülmüştür. Protein açısından buğdaygil ve baklagil türleri arasında farklılıkların oluşması beklenen bir sonuçtur. Çünkü baklagiller buğdaygillerden daha fazla 
protein içeriğine sahiptirler (Linn ve Martin, 1999). Karışımların ham protein oranlarına bakıldığında ise ikili karışımlar içerinde yoncanın bulunduğu karışımların ham protein oranlarının gazal boynuzunun bulunduğu ikili karışımlardan daha yüksek olduğu saptanmıştır. Üçlü karışımlarda ise yine yoncanın yer aldığı karışımlar, gazal boynuzunun yer aldığı üçlü karışımlardan daha yüksek HPO’ya sahip olduğu görülmüştür (Çizelge 3). Bunun sebebinin yoncanın birim alanda elde edilen verime katkısının (payının) gazal boynuzundan daha yüksek olmasından kaynaklandığı düşünülmektedir (Temel ve Akbay Tohumcu, 2019). İki yıllık ortalama sonuçlara göre mevcut çalışmada türlerin yalın ekim ve karışımlarının ham protein oranları, Türkiye'nin farklı ekolojilerinde yapılan çalışmalardan daha düşük bulunmuştur (Kaplan ve ark., 2009; Kır, 2010; Kökten ve ark., 2011). Bu farklılığın nedeninin ekolojik koşulların yanı sıra kültürel uygulamaların ve araştırmada kullanılan çeşitlerin farklıı̆ı̆ından kaynaklandığı söylenebilir.

Çizelge 3. Yalın ekim ve karışımların ham protein oranları ve ham protein verimleri

\begin{tabular}{|c|c|c|c|c|c|c|c|}
\hline \multirow[b]{3}{*}{ Konular } & \multicolumn{3}{|c|}{ Ham Protein Oranı (\%) } & \multicolumn{4}{|c|}{ Ham Protein Verimi (kg/da) } \\
\hline & \multicolumn{3}{|c|}{ Crude Protein Ratios (\%) } & \multicolumn{4}{|c|}{ Crude Protein Yields } \\
\hline & 2015 & 2016 & Ortalama & Konular & 2015 & 2016 & Ortalama \\
\hline $\mathbf{Y}$ & 15.21 & 15.24 & $15.22 a^{* *}$ & $\mathbf{Y}$ & 213.38 & 115.25 & $164.31 \mathrm{a}$ \\
\hline GB & 15.40 & 16.28 & $15.84 \mathrm{a}$ & GB & 113.90 & 88.80 & $101.35 \mathrm{c}$ \\
\hline KY & 7.23 & 7.88 & $7.56 \mathrm{e}$ & KY & 41.35 & 32.87 & $37.11 \mathrm{f}$ \\
\hline KB & 8.31 & 8.24 & $8.27 \mathrm{de}$ & KB & 35.76 & 29.97 & $32.86 \mathrm{f}$ \\
\hline$K Y+Y$ & 13.32 & 13.59 & $13.45 \mathrm{~b}$ & $K Y+Y$ & 141.46 & 90.35 & $115.91 \mathrm{~b}$ \\
\hline$K Y+G B$ & 11.48 & 7.28 & $9.60 \mathrm{c}$ & $K Y+G B$ & 74.54 & 32.20 & $53.37 \mathrm{e}$ \\
\hline$K B+Y$ & 13.58 & 13.22 & $13.40 \mathrm{~b}$ & $K B+Y$ & 69.75 & 42.84 & $56.3 \mathrm{e}$ \\
\hline$K B+G B$ & 10.35 & 10.10 & $10.23 \mathrm{c}$ & $\mathrm{KB}+\mathrm{GB}$ & 32.69 & 24.14 & $28.42 \mathrm{f}$ \\
\hline$K Y+K B+Y$ & 9.31 & 8.82 & $9.06 \mathrm{~cd}$ & $K Y+K B+Y$ & 86.08 & 62.90 & $74.49 d$ \\
\hline$K Y+K B+G B$ & 8.00 & 7.89 & $7.95 \mathrm{de}$ & $K Y+K B+G B$ & 68.42 & 45.87 & $57.14 \mathrm{e}$ \\
\hline Ortalama & 11.22 & 10.90 & 11.04 & Ortalama & $87.73 \mathrm{~A}$ & $56.52 \mathrm{~B}$ & 72.13 \\
\hline $\begin{array}{l}\text { F değerleri ve } \\
\text { önemlilik }\end{array}$ & \multicolumn{3}{|c|}{$\begin{array}{l}\text { Y:1.446 ö.d., K: } 55.146^{* *}, \\
\text { Y X K: } 2.313^{*}\end{array}$} & $\begin{array}{l}\text { F değerleri ve } \\
\text { önemlilik }\end{array}$ & \multicolumn{3}{|c|}{$\begin{array}{l}\text { Y: } 168.230 * *, K: 128.778 * * \\
\text { Y x K: } 13.179 * *\end{array}$} \\
\hline
\end{tabular}

** Aynı sütunda farklı harfle gösterilen ortalamalar arasında 0.01 düzeyinde fark vardır. * Aynı sütunda farklı harfle gösterilen ortalamalar arasında 0.05 düzeyinde fark vardır. Y: Yıl, K: Konular

Yıl $x$ konu interaksiyonu açısından incelendiğinde, en yüksek ham protein oranları 2015 ve 2016 yılında hasat edilen yonca ve gazal boynuzu bitkisinde, en düşük değerler ise her iki yılda da yalın ekilen buğdaygil ve üçlü karışımlar ile 2016 yılında hasat edilen $\mathrm{KY}+\mathrm{GB}$ karışımlarında belirlenmiştir (Şekil 1). Türlerin karışım ve yıllara göre farklı tepki vermesi konu $x$ yıl interaksiyonunun önemli çıkmasına neden olmuştur.

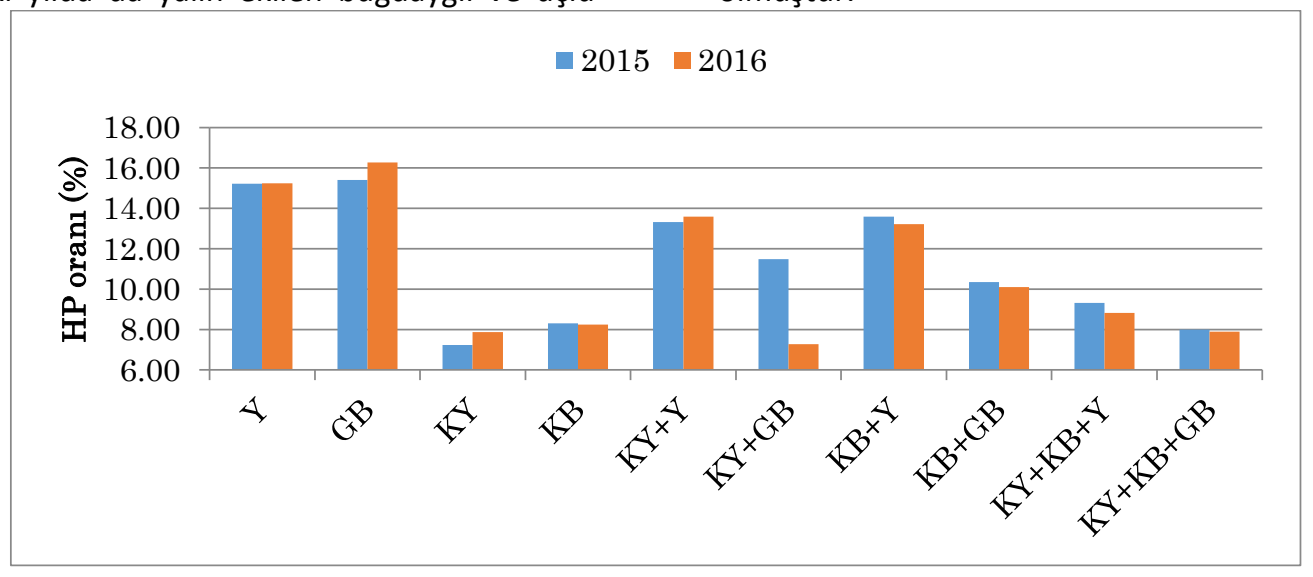

Şekil 1. Ham protein oranı üzerine yıl x konu interaksiyonun etkisi 


\section{Ham protein verimi}

Yalın ekim ve karışımların ortalama ham protein verimleri Çizelge $3^{\prime}$ te verilmiştir. İstatistik analiz sonucu ham protein verimi bakımından konular arasında çok önemli farklılıklar belirlenmiştir $(P<0.01)$. Konular içerisinde en yüksek ham protein verimi yalın ekilen yoncadan, en düşük ham protein verimleri ise $28.42,32.86$ ve $37.11 \mathrm{~kg} / \mathrm{da}$ değerleri ile sırası ile $K B+G B$ ikili karışımı, kılçıksız brom ve kamışsı yumağın yalın ekimlerinden elde edilmiştir. Bilindiği üzere ham protein verimi, ham protein oranı ile kuru ot verimin çarpılması sonucunda elde edilen bir değerdir. Mevcut çalışmamızda da KY, KB ve $K B+G B$ karışımların ham protein içeriklerinin yoncadan daha düşük olduğu belirlenmiştir. Ayrıca Temel ve Akbay Tohumcu (2019) yürüttükleri bir çalışmada karışıma giren bitkiler içerisinde en yüksek kuru ot veriminin yalın ekilen yoncadan, en düşük değerlerin de $K Y, K B$ ve $K B+G B$ karışımından elde edildiğini ortaya koymuşlardır. Bu bulgular bizim sonuçlarımızı destekler niteliktedir.

Ham protein verimi bakımından yıllar arasında da önemli farklılıklar gözlenmiştir. 2015 yılında yalın ekim ve karışımların ham protein verimleri ortalaması $87.73 \mathrm{~kg} / \mathrm{da}$ iken 2016 yılında $56.52 \quad \mathrm{~kg} / \mathrm{da} a$ düştüğü belirlenmiştir. Yıllar arasındaki bu farklılığın sebebinin iki yıl arasındaki iklim koşullarının farklılığından kaynaklandığı söylenebilir (Çizelge 1). Yalın ekim ve karışımların ham protein verimleri konu $\mathrm{x}$ yıl etkileşimi açısından \%1 seviyesinde farklılık göstermiştir (Şekil 2).

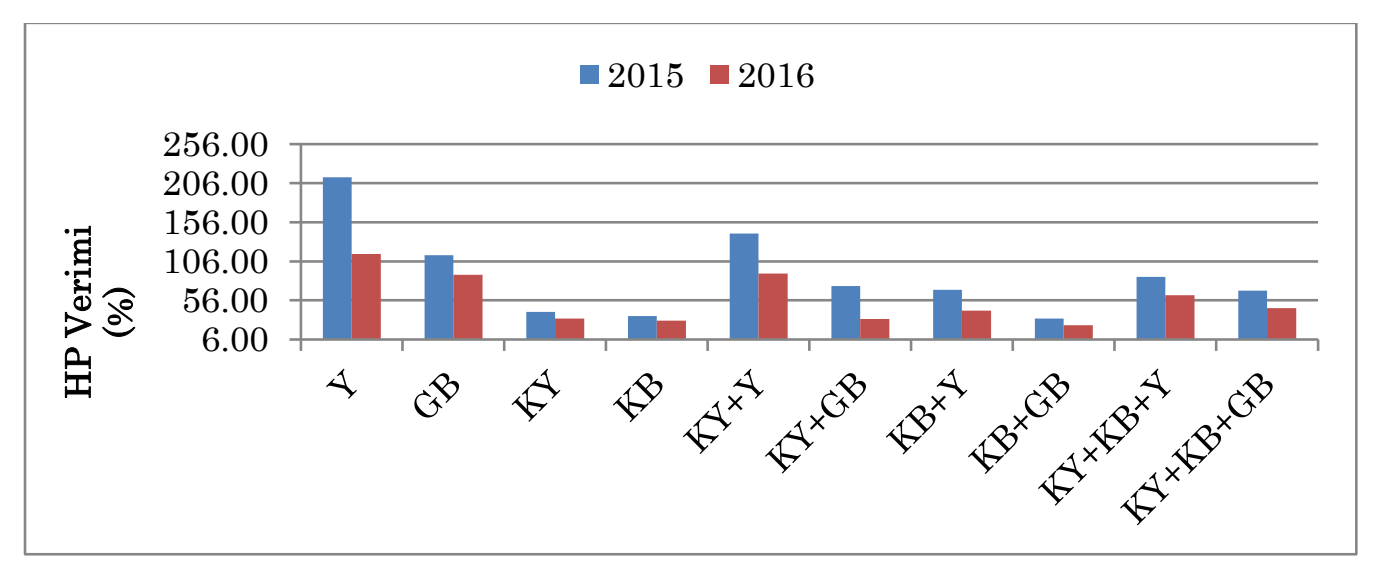

Şekil 2. Ham protein verimi üzerine yıl x konu interaksiyonun etkisi

\section{NDF Oranları}

Saf ekim ve karışımların NDF oranları Çizelge 4'te verilmiştir. Yapılan istatistik analiz sonucunda NDF oranları bakımından konular arasında önemli farklılıklar belirlenmiştir $(P<0.01)$. Konular içerisinde en düşük NDF oranı \% 38.85 ile gazal boynuzunun yalın ekiminden elde edilmiştir. En yüksek NDF oranları istatistiksel olarak aynı grupta yer alan $K Y$, $\mathrm{KY}+\mathrm{KB}+\mathrm{Y}$ ve $\mathrm{KY}+\mathrm{KB}+\mathrm{GB}$ 'den elde edilmiş olup, NDF oranları sırası ile; \% 63.38, \% 63.1 ve \% 61.95 olarak belirlenmiştir. Yemin sindirilebilirliğini ifade eden ADF ve NDF oranlarının bitkiye, türe hatta çeşide göre farklılık göstermektedir (Tan ve Menteşe, 2003; Yavuz, 2005). Buğdaygillerin NDF oranlarının baklagillerden daha yüksek olduğu bilinmektedir, böylece baklagillerin sindirilebilirlik oranları daha yüksektir (Linn ve
Martin, 1999). Araştırma sonucuna göre mevcut çalışmada yalın ekim ve karışımların NDF oranları, Türkiye'nin farklı ekolojilerinde yapılan çalışmalardan daha düşük bulunmuştur (Ijptaş ve ark. 2007; Yavuz ve Karadağ, 2016). Bunun sebebinin çeşit farklılığı, ekolojik koşullar, yapılan kültürel uygulamalar ve bitkilerin biçim dönemlerindeki farklılıklar olduğu söylenebilir.

\section{ADF Oranları}

Yalın ekim ve karışımlara ait ADF oranları Çizelge 4'te verilmiştir. Yapılan istatistik analiz sonucunda ADF oranları bakımından konular arasında çok önemli farklılıklar belirlenmiştir $(P<0.01)$. Konular içerisinde en düşük ADF oranı \% 27.04 ile gazal boynuzunun yalın ekiminden elde edilmiştir. Karışımlardan $K Y+G B$ ve $K B+Y$ ikili karışımları yalın ekilen yonca ile istatistiki 
olarak farklılıkları bulunmamaktadır ve yalın ekilen yonca, $\mathrm{KY}+\mathrm{GB}$ ve $\mathrm{KB}+\mathrm{Y}$ ikili karışımlarının ADF oranlarının sırası ile; $\% 30.75, \% 32.27$ ve \% 33.49 olduğu belirlenmiştir. En yüksek ADF oranları ise kamışsı yumağın yalın ekimi ve $K Y+K B+Y$ üçlü karışımından elde edilmiş olup ADF oranları sırası ile; \% 39.92 ve \% 41.51'dir. Yalın ekim ve karışımların ADF oranları bakımından yıllar arasında önemli bir farklılık bulunmamıştır. İki yıllık ortalama sonuçlara göre ADF oranları \% 27.04 ile \% 41.51 arasında değişiklik göstermiştir. Mevcut araştırma sonucunda yalın ekim ve karışımların ADF oranlarının, Türkiye'nin farklı bölgelerinde yapılan çalışmaların bazılarından düşük (Avcı, 2000; Yavuz ve Karadağ, 2016), bazılarından ise daha yüksek (Baron ve ark.,2000; Iptaş ve ark., 2007) olduğu belirlenmiştir. Çalışmalar arasındaki farklılıkların sebebinin ekolojik koşulların farklı olmasının yanı sıra çeşit farklılığı, biçim zamanlarının farklılığı ve yapılan kültürel uygulamaların farklılığından kaynaklandığı söylenebilir.

Çizelge 4. Yalın ekim ve karışımların NDF ve ADF oranları

\begin{tabular}{|c|c|c|c|c|c|c|c|}
\hline \multirow{2}{*}{ Konular } & \multicolumn{3}{|c|}{ NDF (\%) } & \multirow[b]{2}{*}{ Konular } & \multicolumn{3}{|c|}{ ADF (\%) } \\
\hline & 2015 & 2016 & Ortalama & & 2015 & 2016 & Ortalama \\
\hline $\mathbf{Y}$ & 44.72 & 44.98 & $44.85 \mathrm{~d}$ & $\mathbf{Y}$ & 31.05 & 30.44 & $30.75 \mathrm{~d}$ \\
\hline GB & 38.32 & 39.38 & $38.85 \mathrm{e}$ & GB & 27.21 & 26.88 & $27.04 \mathrm{e}$ \\
\hline KY & 63.57 & 63.19 & $63.38 \mathrm{a}$ & KY & 39.84 & 39.99 & $39.92 a b$ \\
\hline KB & 55.59 & 55.38 & $55.49 \mathrm{~b}$ & KB & 34.91 & 34.90 & $34.91 \mathrm{c}$ \\
\hline$K Y+Y$ & 50.43 & 52.49 & 51.46 bc & $K Y+Y$ & 33.82 & 34.72 & $34.27 c$ \\
\hline$K Y+G B$ & 49.43 & 49.46 & $49.45 c$ & $K Y+G B$ & 31.99 & 32.54 & $32.27 \mathrm{~cd}$ \\
\hline$K B+Y$ & 50.43 & 52.49 & 51.46 bc & $K B+Y$ & 33.25 & 33.73 & $33.49 \mathrm{~cd}$ \\
\hline$K B+G B$ & 51.65 & 52.64 & 52.15 bc & $K B+G B$ & 34.58 & 34.51 & $34.55 c$ \\
\hline$K Y+K B+Y$ & 63.07 & 63.14 & $63.1 \mathrm{a}$ & $K Y+K B+Y$ & 41.58 & 41.44 & $41.51 \mathrm{a}$ \\
\hline$K Y+K B+G B$ & 62.04 & 61.86 & $61.95 \mathrm{a}$ & $\mathrm{KY}+\mathrm{KB}+\mathrm{GB}$ & 38.43 & 38.50 & $38.46 \mathrm{~b}$ \\
\hline Ortalama & 52.93 & 53.50 & 53.21 & Ortalama & 34.67 & 34.77 & 34.72 \\
\hline \multicolumn{4}{|c|}{ F değerleri ve önemlilik } & \multicolumn{4}{|c|}{ F değerleri ve önemlilik } \\
\hline \multicolumn{4}{|c|}{ Y:0.080ö.d., K: $26.758^{* *}$, Y x K: $0.077^{\text {ö.d. }}$} & \multicolumn{4}{|c|}{ 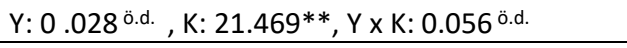 } \\
\hline
\end{tabular}

** Aynı sütunda farklı harfle gösterilen ortalamalar arasında 0.01 düzeyinde fark vardır. Y: Yıl, K: Konular

\section{Sindirilebilir Kuru Madde}

İki yıllık araştırma sonuçlarına göre yalın ekim ve karışımların SKM değerleri Çizelge 5'te verilmiştir. Yapılan istatistik analiz sonucunda SKM değerleri bakımından konular arasında çok önemli farklılıklar belirlenmiştir $(P<0.01)$. Yalın ekim ve karışımlar arasında en yüksek SKM oranı \% 67.83 ile gazal boynuzunun yalın ekiminden elde edilmiştir. Yalın ekilen yoncanın SKM oranı ile ikili karışımlardan $K Y+G B$ ve $K B+Y$ istatistiksel olarak aynı grupta yer almışlar ve yalın ekilen gazal boynuzundan sonra en yüksek SKM oranı değerlerine sahiptirler. En düşük SKM oranları sırası ile \%56.56 ve \%57.81 ile $K Y+K B+Y$ ve yalın ekilen kılçıksız bromdan elde edilmiştir. Yalın ekilen baklagillerin ve ikili karışımların SKM oranlarının yalın ekilen buğdaygiller ve üçlü karışımlardan daha yüksek olduğu belirlenmiştir. Yalın ekim ve karışımların SKM oranları bakımından yıllar arasında önemli bir farklılık bulunmamıştır. İki yıllık ortalama sonuçlara göre yalın ekim ve karışımların SKM oranları \%56.56 ile \%67.83 arasında değişmiştir. Mevcut araştırmadan elde edilen yalın ekim ve karışımlara ait SKM değerleri Yavuz (2011)'un yaptığı çalışma ile benzerlik göstermektedir.

\section{Nispi Yem Değeri}

Yalın ekim ve karışımların NYD Çizelge 5 'te verilmiştir. NYD bakımından yalın ekim ve karışımlar arasında çok önemli farklılıklar belirlenmiştir $(P<0.01)$. NYD; yem bitkisinin kimyasal değerlerini kullanarak yem kalitesinin ölçülmesidir. Fakat NYD yemin protein oranı hakkında bilgi vermez (Yavuz, 2005). Konular arasında en yüksek NYD 162.74 ile yalın ekilen gazal boynuzundan elde edilmiştir. Yalın ekilen buğdaygillerden sonra en yüksek NYD ikili karışımlardan elde edilmiştir. En düşük NYD; $K Y+K B+Y$ üçlü karışımından, kamışsı yumağın yalın ekiminden ve $K Y+K B+G B$ üçlü karışımından $83.73,84.95$ ve 88.91 değerleri ile elde edilmiştir. Yalın ekim ve karışımların NYD bakımından yıllar arasında önemli bir farklılık bulunmamıştır. Araştırmadan elde edilen iki yıllık ortalama sonuçlara göre yalın ekim ve karışımların NYD 83.73 ile 162.74 arasında değişmiştir. NYD 100'ün altına düştükçe yem 
kalitesi azalmakta, tam tersi durumda ise artmaktadır. Yoncada 100 NYD normal yonca değeri olarak kabul edilmektedir (Yavuz, 2005). Mevcut araştırmada yalın ekilen yoncanın 135.11 NYD'ne sahip olduğu ve bu değer araştırmada kullanılan yonca çeşidinin yüksek yem kalitesine sahip olduğunu göstermektedir. Bazı ruminant yemlerine ait NYD'nin belirlendiği araştırmada, Yavuz (2005) yoncanın 118.8 ve kamışsı yumağın 67.7 NYD'ne sahip olduğunu bildirmişlerdir. Bu değerler mevcut çalışmadaki değerlerden düşüktür. Çalışmalar arasındaki farklığa, ekolojik koşulların farklı olmasının, çeşit farklılığının ve yapılan kültürel işlemlerin farklılığının sebebiyet verdiği söylenebilir.

Çizelge 5. Yalın ekim ve karışımların SKM oranları ve NYD

\begin{tabular}{|c|c|c|c|c|c|c|c|}
\hline \multirow[b]{3}{*}{ Konular } & \multicolumn{3}{|c|}{ SKM (\%) } & \multirow[b]{3}{*}{ Konular } & \multicolumn{3}{|c|}{ NYD } \\
\hline & \multicolumn{3}{|c|}{ Digestible Dry Matter (\%) } & & \multicolumn{3}{|c|}{ Relative Feed Value } \\
\hline & 2015 & 2016 & Ortalama & & 2015 & 2016 & Ortalama \\
\hline $\mathbf{Y}$ & 64.71 & 65.18 & $64.95 \mathrm{~b}$ & $\mathbf{Y}$ & 135.24 & 134.97 & $135.11 \mathrm{~b}$ \\
\hline GB & 67.70 & 67.96 & $67.83 \mathrm{a}$ & GB & 164.60 & 160.87 & $162.74 \mathrm{a}$ \\
\hline KY & 57.86 & 57.75 & $57.81 \mathrm{de}$ & KY & 84.75 & 85.16 & 84.95 e \\
\hline KB & 61.71 & 61.71 & $61.71 \mathrm{c}$ & KB & 103.31 & 103.77 & $103.54 \mathrm{~d}$ \\
\hline$K Y+Y$ & 62.55 & 61.86 & $62.2 \mathrm{c}$ & $K Y+Y$ & 111.97 & 111.42 & $111.69 \mathrm{~cd}$ \\
\hline $\mathrm{KY}+\mathrm{GB}$ & 63.98 & 63.55 & 63.76 bc & $K Y+G B$ & 121.36 & 120.55 & $120.96 c$ \\
\hline$K B+Y$ & 63.00 & 62.62 & $62.81 \mathrm{bc}$ & $K B+Y$ & 116.20 & 112.67 & $114.43 \mathrm{~cd}$ \\
\hline$K B+G B$ & 61.96 & 62.01 & $61.99 c$ & $\mathrm{~KB}+\mathrm{GB}$ & 112.14 & 110.61 & $111.37 \mathrm{~cd}$ \\
\hline$K Y+K B+Y$ & 56.51 & 56.62 & $56.56 \mathrm{e}$ & $K Y+K B+Y$ & 83.70 & 83.76 & 83.73 e \\
\hline$\underline{K Y+K B+G B}$ & 58.97 & 58.91 & $58.94 \mathrm{~d}$ & $K Y+K B+G B$ & 88.84 & 88.99 & $88.91 \mathrm{e}$ \\
\hline Ortalama & 61.90 & 61.82 & 61.86 & Ortalama & 112.21 & 111.28 & 111.74 \\
\hline \multicolumn{4}{|l|}{ F değerleri ve önemlilik } & \multicolumn{4}{|c|}{ F değerleri ve önemlilik } \\
\hline \multicolumn{4}{|c|}{ Y: $0.028^{\text {ö.d. }, ~ K: ~} 21.469 * *, Y \times$ K: $0.056^{\text {o.d. }}$} & \multicolumn{4}{|c|}{ 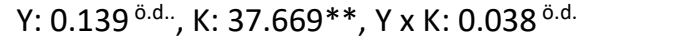 } \\
\hline
\end{tabular}

** Aynı sütunda farklı harfle gösterilen ortalamalar arasında 0.01 düzeyinde fark vardır. Y: Yıl, K: Konular

Sonuç

Iğdır iline benzer ekolojik koşullara ve toprak özelliklerine sahip alanlarda ham protein ve sindirilebilirlik gibi kaliteyi etkileyen özellikler dikkate alınarak bir suni mera tesisi planlandığında bölge açısından en uygun karışımların yonca bitkisinin bulunduğu ikili karışımlar olduğu yapılan çalışma sonucunda görülmektedir yani bölge için bu karışımlar önerilebilir.

\section{Teşekkür}

Bu araştırma Iğdır Üniversitesi Bilimsel Araştırma Projeleri Koordinasyon Birimince desteklenmiştir. Mevcut çalışmanın (2014-FBEB12) tüm finansman desteğini sağlayan Iğdır Üniversitesi BAP birimine katkılarından dolayı teşekkür ederiz.

\&: Bu çalışma, 25-27 Nisan 2018 tarihinde Şanlıurfa'da düzenlenen 1. Uluslararası GAP Tarım ve Hayvancılık Kongresi (UGAP2018)'nde özet bildiri olarak sunulmuştur.

\section{Kaynaklar}

Açıkgöz, E., 2001. Yem Bitkileri. Uludağ Üni. Zir. Fak. Tarla Bit. Böl. Uludağ Üni. Basımevi, 3.baskı. Bursa. 584 s.

Albayrak, S., 2003. Ankara Ekolojik Koşullarında Yapay Mera Kurulması Üzerine Bir Araştırma. Ankara Üniversitesi Fen Bilimleri Enstitüsü, Tarla Bitkileri Ana Bilim Dalı, Doktora Tezi, Ankara, s. 166. Anonim, 2016. Iğdır iı Meteoroloji Müdürlüğü. Anonim, 2020. https://igdir.tarimorman.gov.tr/Menu/ 20/Ilimiz Erişim tarihi: 08.06.2020.

Avcı, M., 2000. Çukurova'da Geçici Yapay Mera Kurma Amacıyla Yetiştirilebilecek Kışlık Çok Yıllık Buğdaygil+Baklagil Yem Bitkileri Karışımlarının Saptanması. Doktora Tezi Ç.Ü.Fen Bilimleri Enstitüsü, Adana.

Baron, VS, Alistair, CD, King, JR, 2000. Leaf and stem mass characteristics of coolseason grasses grown in the canadian parkland. Agronomy Journal, 92:54-63. 
Çınar, S., Avcl, M., Hatipoğlu, R., Aktaş, A., and Kökaşık, F. D. 2012. "Çukurova Taban Koşullarında Bazı Çokyıllık Sıcak Mevsim Buğdaygiller ile Baklagil Karışımlarının Performanslarının Saptanması," Tarım Bilimleri Araştırma Dergisi TABAD, vol. 5, no. 2, pp. 14-18, Sep.

Iptaş, S., Karadağ, Y. ve Acar, A. 2007. TokatKazova Ekolojik Koşullarına Uygun Yonca (Medicago sativa L.) Çeşitlerinin Belirlenmesi. Türkiye 4. Tarla Bitkileri Kongresi, 25-27 Haziran, Erzurum 297301.

Kacar, B., 1972. Bitki ve Toprağın Kimyasal Analizleri II. Bitki analizleri. Ank. Üniv. Basımevi, Ankara s. 646

Kacar, B., 1986. Gübreler ve Gübreleme Tekniği. T.C. Ziraat Bankası Kültür Yayınları No: 20, 474, Ankara.

Kaplan, M., Atalay, A.I., Medjekal, S. 2009. Potential nutritive value of wild birdsfoot trefoil (Lotus corniculatus) plants grown in different sites. LivestockResearch for Rural Development, 21 (7), 99-102.

Kır, H. 2010. Tokat-Kazova Şartlarında Bazı Yonca Çeşitlerinin Performanslarının Belirlenmesi. Yüksek Lisans Tezi, Gaziosmanpaşa Üniversitesi Fen Bilimleri Enstitüsü, Tokat.

Koç, A., Gökkuş, A., Tan, M., Çomaklı, B., Serin, Y., 2004. Performance of tall fescue and lucerne-tall frescue mixtures in highlands of Turkey. New Zealand Journal of Agricultral Research, 47: 6165.

Kökten, K., S., Çınar, R., Hatipoğlu, 2011. Çukurova Bölgesinin Sulu Koşullarında Bazı Çokyıllık Baklagil ve Buğdaygil Yembitkilerinin Ot Verimleri ve Ot Kaliteleri Üzerinde Araştırmalar. IX. Tarla Bitkileri Kongresi Sunulu Bildiri, 3. Cilt.s. 1668-1673. 12-15 Eylül Bursa.

Linn, J.G., Martin, N.P. 1999. Forage quality tests and interpretations. Minnesota Extension Service, University of Minnesota Publ. FO-02637, St. Paul

Oddy, V.H., Robards, G.E., Low, S.G. 1983. Prediction of in vivo dry matter digestibility from the fiber nitrogen content of a feed. In: Robards, G.E., Packham, R.G. (Eds.), Feed Information and Animal Production.
Commonwealth Agricultural Bureaux, Farnham Royal, UK, pp. 395-398.

Özaslan-Parlak, A., Ekiz, H. 2006. Bazı yapay mera karışımlarında ekim yöntemleri ve azot dozlarının fide gelişmesine etkileri. Ankara Üni. Ziraat Fakültesi Tarım Bilimleri Dergisi, 12 (2): 203-209

Seydoşoğlu, S., Bengisu, G., 2019. Effects of different mixture ratios and harvest periods on grass quality of triticale (xTriticosecale wittmack)-forage pea (Pisum sativum L.) intercrop. Applied Ecology and Environmental Research 17(6):13263-13271.

Sheaffer, C. C., Peterson M. A., Mccalın M., Volene J.J., Cherney,J.H., Johnson K.D.,Woodward W.T. ve Viands D.R., 1995. Acid Detergent Fiber, Neutral Detergent Fiber Concentration And Relative Feed Value, North American Alfalfa Improvement Conference, Minneapolis.

Şahinoğlu, O., Uzun, F., 2016. Taban mera ıslahında farklı metotların etkinliği: I. Agronomik özellikler. Anadolu Tarım Bilimleri Dergisi, 31(3): 423-432.

Tan, M. ve Menteşe Ö. 2003. Effects of anatomic structure and chemical composition on forage quality. Atatürk University Journal of the Faculty of Agriculture 34: 97-103.

Tan, M., 2018. Baklagil ve Buğdaygil Yem Bitkileri. Erzurum: Atatürk Üniversitesi Ziraat Fakültesi Ders Yayınları No: 256.

Temel, S., Akbay Tohumcu, S., 2019. Iğdır Taban Koşullarında Kaba Yem Üretimi İçin Bazı Buğdaygil ve Baklagil Karışımlarının Verim Performansları. Uluslararası Tarım ve Yaban Hayatı Bilimleri Dergisi (UTYHBD), 5(1): 140148.

Temel, S., Şahin K. 2010. Iğdır ilinde yem bitkilerinin mevcut durumu, sorunları ve çözüm önerileri. Yüzüncü Yıl Üniversitesi Tarım Bilimleri Dergisi, 21, 64-72.

Temel, S., Şimşek U. 2011. Iğdır Ovası toprakların çoraklaşma süreci ve çözüm önerileri. Alınteri 21, 53-59.

Van Soest, P.J., Robertson, J.B., ve LewIS, B.A., 1991. Method for Dietary Fiber, Neutral Detergent Fiber, and Nonstarch Polysaccharides in Relation to Animal Nutrition. J. Dairy Sci., 74: 3583- 3597. 
Yavuz, M. 2005. Bazı ruminant yemlerinin nispi yem değeri ve in vitro sindirim değerlerinin belirlenmesi. Gaziosmanpaşa Üniversitesi Ziraat Fakültesi Dergisi 22 (1): 97-101.

Yavuz, T. 2011. Karadeniz Bölgesi Geçit İklim Kuşağı Kıraç Alanlarında Yapay Mera Karışımlarının Belirlenmesi. Doktora tezi. Gaziosmanpaşa Üniversitesi Fen Bilimleri Enstitüsü, Tokat.
Yavuz, T. ve Karadağ, Y. 2016. Kıraç koşullarda yapay mera karışımlarının verim ve kalite performansları. Iğdır Üniversitesi Fen Bilimleri Enstitüsü Dergisi, 6, 155163.

Yolcu, H. ve Tan M. 2008. Ülkemiz yem bitkileri tarımına genel bir bakış. Tarım bilimleri Dergisi 14 (3): 303-312. 